\title{
DOPERS IN UNIFORM
}




\section{Also by John Hoberman}

Age of Globalization (2014)

Black and Blue: The Origins and Consequences

of Medical Racism (2012)

Testosterone Dreams: Rejuvenation, Aphrodisia,

Doping (2005)

Doping and Public Policy, coeditor (2004)

Darwin's Athletes: How Sport Has Damaged Black

America and Preserved the Myth of Race (1997)

Mortal Engines: The Science of Performance and

Dehumanization of Sport (1992)

The Olympic Crisis: Sport, Politics, and the Moral

Order (1986)

Sport and Political Ideology (1984)

\section{TERRY AND JAN TODD SERIES ON PHYSICAL CULTURE AND SPORTS}

\section{Also in the Todd Series}

Mr. America: The Tragic History of a Bodybuilding Icon by John D. Fair (2015)

Drug Games: The International Olympic Committee and the Politics of Doping, 1960-2008 by Thomas Hunt (2011) 

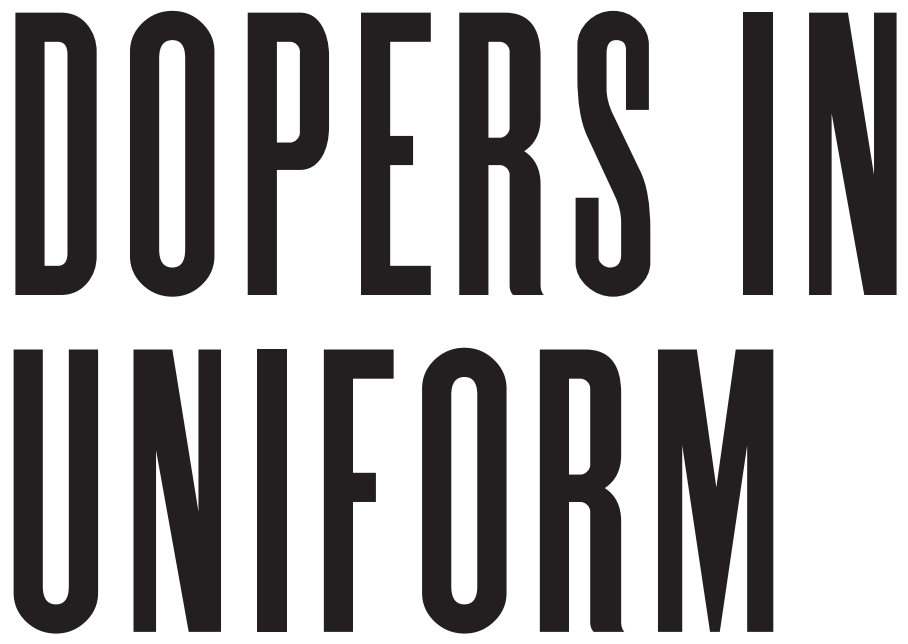

THE HIDDEN WORLD OF POLICE ON STEROIDS

JOHN HOBERMAN

UNIVERSITY OF TEXAS PRESS, AUSTIN 4 
Copyright (C) 2017 by the University of Texas Press

All rights reserved

Printed in the United States of America

First edition, 2017

Requests for permission to reproduce material from this work should be sent to:

Permissions

University of Texas Press

P.O. Box 7819

Austin, TX 78713-7819

utpress.utexas.edu/rp-form

The paper used in this book meets the minimum requirements of ANSI/NISO Z39.48-1992 (R1997) (Permanence of Paper). @

Library of Congress Cataloging Data

Names: Hoberman, John M. (John Milton), 1944- author.

Title: Dopers in uniform : the hidden world of police on steroids / John Hoberman.

Description: First edition. | Austin : University of Texas

Press, 2017. | Includes bibliographical references and index.

Identifiers: LCCN 2016058736

ISBN 978-0-292-75948-o (cloth : alk. paper)

ISBN 978-1-4773-1397-8 (library e-book)

ISBN 978-1-4773-1398-5 (non-library e-book)

Subjects: LCSH: Police-Drug use-United States. |

Police-Drug testing-United States. | Steroid abuse.

Classification: LCC HV7936.D78 H63 2017 | DDC

$362.29 / 9-\mathrm{dc} 23$

LC record available at https://lccn.loc.gov/2016058736

doi: $10.7560 / 759480$ 
We cannot have a grown-up conversation about race in America until we acknowledge the violent conditions engendered by government policy and police practice.

- REVEREND DR. WILLIAM BARBER II, president of the North Carolina NAACP

The physical dangers of police work are grossly overrated but the emotional dangers make it the most hazardous job on earth.

-JOSEPH WAMBAUGH, The Choirboys 
THIS PAGE INTENTIONALLY LEFT BLANK 